ISSN 0103-5150

Fisioter. Mov., Curitiba, v. 29, n. 3, p. 497-506, Jul./Set. 2016

Licenciado sob uma Licença Creative Commons

DOI: http://dx.doi.org.10.1590/1980-5918.029.003.A007

(c) (i)

\title{
Effects of hippotherapy on posture in individuals with Down Syndrome
}

\author{
Efeitos da equoterapia na postura de \\ indivíduos com Síndrome de Down
}

Ana Paula Espindula, Mariane Fernandes Ribeiro, Luciane Aparecida Pascucci Sande de Souza, Alex Abadio Ferreira, Mara Lúcia da Fonseca Ferraz, Vicente de Paula Antunes Teixeira*

Universidade Federal do Triângulo Mineiro, (UFTM), Uberaba, MG, Brazil

\begin{abstract}
Introduction: Individuals with Down syndrome (DS) have alterations that affect the musculoskeletal system, causing abnormal patterns, and alter the morphological anatomical and mechanical axes that provide intrinsic stability to the skeleton, and can trigger misalignments and orthopedic disorders in adulthood. Objective: The objective of student to evaluate posture and postural alignment before and after the hippotherapyin individuals with DS. Methods: Posture of five individuals with DS was evaluated by the software SAPO before and after 27 sessions the hippotherapy. Data were subjected to qualitative descriptive analysis using cluster and statistical analysis with the aid of the software Sigma Stat 2.0, considering differences as statistically significant at p-value < 5\%. Results: Improvements were achieved for the alignment of shoulder, head, hip, and lower limbs, in addition to decrease in kyphosis and head protrusion. Conclusion: Patients with DS demonstrated satisfactory changes in motor behavior reflected in improved static posture after treatment with hippotherapy.
\end{abstract}

\footnotetext{
*APE: PhD, e-mail: anapaulaespindula@yahoo.com.br

MFR: Doctoral student, e-mail: maryanefernandes@yahoo.com.br

LAPSS: PhD, e-mail: lusande@gmail.com

AAF: BS, e-mail: alexabferreira@hotmail.com

MLFF: PhD, e-mail: mara@patge.uftm.edu.br

VPAT: PhD, e-mail: vicente@patge.uftm.edu.br
} 
Keywords: Equine-Assisted Therapy. Photogrammetry. Posture. Down Syndrome.

\section{Resumo}

Introdução: Indivíduos com síndrome de Down (SD) apresentam alterações que afetam o sistema musculoesquelético, provocando padrões anormais e alterando os eixos anatômicos morfológicos e mecânicos que proporcionam uma estabilidade intrínseca ao esqueleto, podendo desencadear desalinhamentos e alterações ortopédicas na vida adulta. Objetivo: $O$ objetivo desse estudo foi avaliar a o alinhamento postural antes e após o tratamento equoterapêutico em indivíduos com SD. Métodos: Foram avaliados cinco indivíduos com SD por meio do aplicativo SAPO de avaliação postural, antes e após vinte e sete sessões. Realizou-se a análise qualitativa descritiva por meio do Cluster e análise estatística utilizando o programa Sigma Stat 2.0, considerando estatisticamente significativas as diferenças em que o valor p foi menor que 5\%. Resultados: Foi possível verificar melhoras no alinhamento de ombro, de cabeça, de quadril e membros inferiores, bem como diminuição da cifose e da protrusão de cabeça. Conclusão: Os indivíduos com SD apresentaram mudanças satisfatórias no comportamento motor que refletiram em uma melhora da postura estática após o tratamento na equoterapia.

Palavras-chave: Terapia assistida por cavalos. Fotogrametria. Postura. Síndrome de Down.

\section{Introduction}

Down syndrome (DS) is the most common and well-known chromosomal abnormalities, and is considered one of the most frequent abnormalities of autosomal chromosomes (1). Formerly known as mongolism, it was first described by the English physician John Langdon Down, in 1866 (2). The association of DS with chromosomal alteration was suspected in 1930, and the trisomy 21 (3) was confirmed after about 30 years by independent research.

In general, most individuals with DS has muscle hypotonia caused by decreased segmental excitability of motor neurons and by impaired stretch reflex, generating a decreased sensorimotor control. This causes a slow or ineffective muscle contraction (4). Postural changes in DS may occur due to the difficulty of perception of postural responses, which impairs the feeling of the movement correctly (5).

Thus, muscle activation through activities in children with DS using postural correction techniques helps to reduce the physical impairment (6). Hippotherapy is a physical treatment strategy, in which the horse movement promotes physical and psychological improvements in the overall development of people with or without mobility problems, and is considered a multisensory technique for treating diseases or syndromes with physical or neurological impairments(7). The riding position held by the individual, combined with the movement produced by the horse stride, requires postural adjustments and dissociation of the pelvic and shoulder girdles, causing reactions of trunk rectificationand tonic adjustmentsthat dynamically search for postural stability and control $(8,9)$.

There are reports in the literature that the rhythmic sway of the horse spine stimulates postural reflexes of the hippotherapy patient/ practitioner, resulting in balance training and postural and motor improvements (10). The study of the horse's movement, with its benefits and effectiveness for individuals who use it as a treatment, especially related to health, is continually increasing (11).

In this way, hippotherapy represents a therapeutic approach to improve the postural alignment in DS children who usually present postural changes.

Thus, this study aimed to evaluate the posture before and after hippotherapy treatment in individuals with DS.

\section{Methods}

This was a longitudinal observational study approved by the Research Ethics Committee of the Federal University of Triângulo Mineiro (UFTM), protocol 1502 of 2010, and the assessment methods and intervention protocols followed the rules of Resolution 196/96 of the National Health 
Council on research involving human subjects. The guardians of the individuals included in the study gave written consent,claimed they understood the purpose of this study and the procedures adopted.

\section{Sample characterization}

Previously, medical records of patients with diagnosis of DS attending APAE were analyzed to obtain data such as age, sex and medications in use. For this study, we selected only individuals who were starting the practice of hippotherapy along with the proposed study and were not undergoing conventional physical therapy.

All included participants engaged in psychological treatment once a week in the APAE and did not use controlled drug.

Exclusion criteria were: uncontrolled epilepsy, self-destructive behavior or uncontrollable fear, instability of the spine, hip or shoulder luxation, scoliosis with deviation greater than or equal to 30 degrees and hydrocephalus with valve. The research began with 20 individuals with DS, and at the end, we considered 5 subjects, according to the organization chart (Figure 1) with a mean of 12.6 years $( \pm 3.21)$.

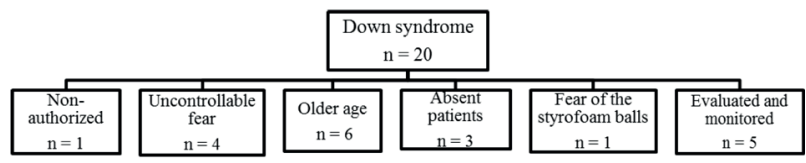

Figure 1 - Representative organization chart of the grounds for exclusion and withdrawal of subjects with Down syndrome.

\section{Procedures}

The sessions and the tests were performed at the Therapeutic Riding Center of APAE, containing roofed area, different textured-floors (dirt track, grass, gravel and cemented), stalls, saddlery and access ramp for practitioners. Sessions $(n=27)$ lasted 30 minutes each, once a week. Postural assessment was performed before the 1st session (1stassessment/initial) and after 27 sessions (2ndassessment/final).

It was set a routesequence for the 30 -minute session based on what is used in clinical practice: Time 1 (T1) up to 7 min and $30 \mathrm{~s}$ on dirt trackon the right direction of the arena; Time 2 (T2) from 7 min $30 \mathrm{~s}$ to 15 min on grass, straight; Time 3 (T3) from 15 min to $22 \mathrm{~min}$ and 30 soncemented gravel ground, straight; Time 4 (T4) from $22 \mathrm{~min} 30$ sto 30 min on dirt track on the left direction of the arena.

During hippotherapy sessions, no activity or extra exercise was performed, being transmitted to the patient only the three-dimensional motion provided by the horse.

\section{Postural Assessment}

Posture of participants was assessed by the software SAPO that, from digitized photographs, measures the linear position, angular position, length and body alignment (12). Photogrammetric analysis with this software is an appropriate qualitative and reliable method for children and adults(13).

A plumb line hanging from the ceiling was placed $30 \mathrm{~cm}$ away from the individual. This line was marked with two Styrofoam balls at a distance of $1 \mathrm{~m}$ from each other, following the software recommendations, to perform the vertical calibration of the images using the application.

Data were collected using a digital camera Sony Veiss Effective 7.2 MP Cyber-Shot, at a height of about half of the individual's height, $3 \mathrm{~m}$ from the child and $3.5 \mathrm{~m}$ from the wall. After marking the points, subjects were positioned at their natural posture on pasteboard fixed to the ground $30 \mathrm{~cm}$ away from the plumb line and their feet were marked on the paper using a graphite, aiming to take photos with the same support base amplitude and positioning of the feet, thus preventing rotation of the trunk and limbs. Photographs were obtained with individuals in swimwear, standing erect in the views: front, rear, left side and right side (Figure 2).

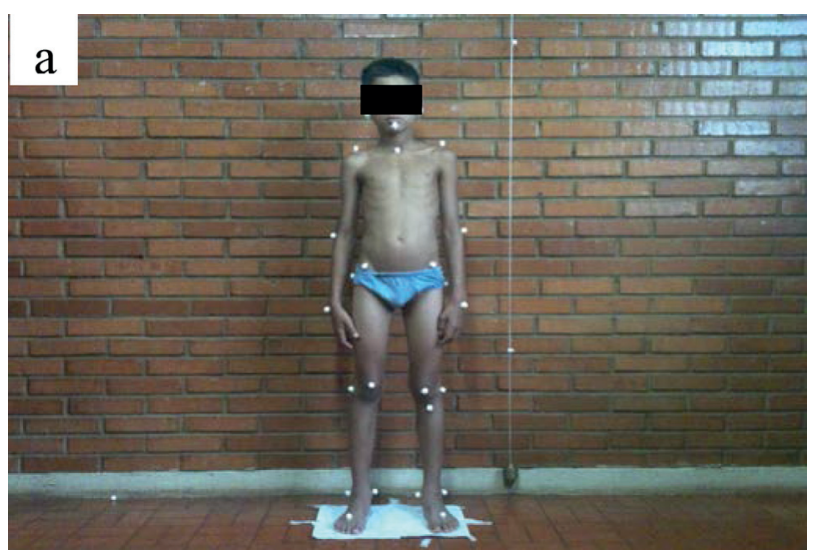



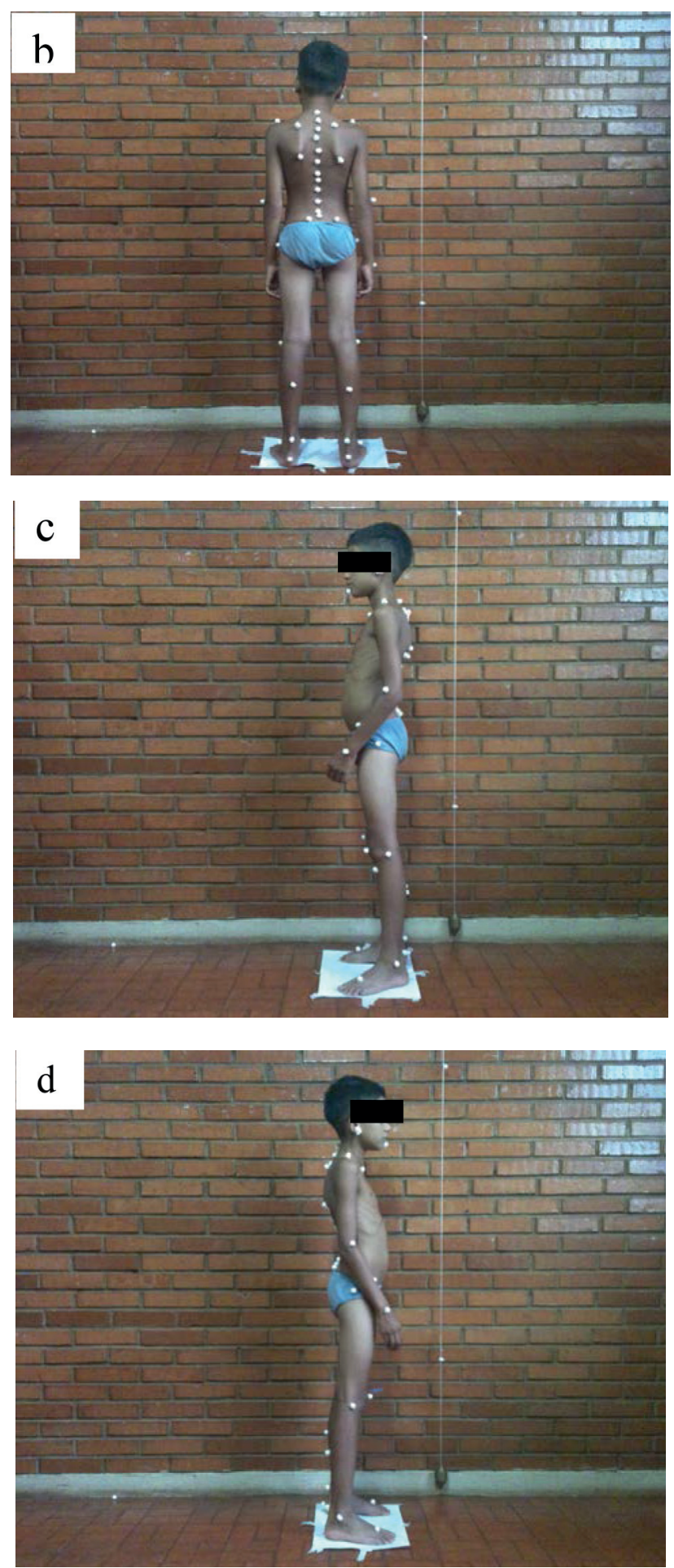

Figure 2 - Position to take the photographs, in the views: (a) front, (b) rear, (c) left side and (d) right side.

Photographs were transferred to the SAPO application, calibrated with the vertical reference to $100 \%$ visualization and analysis was made by means of Styrofoam balls placed on the patient's body, wherein the following distances were evaluated: Front view: 1. from the right acromion to the right anterior superior iliac spine; 2. From the left acromion to the left anterior superior iliac spine; 3 . from the right anterior superior iliac spine to the right medial malleolus; 4 . from the left anterior superior iliac spine to the left medial malleolus. Rear view: 5 . from the right acromion to the right posterior superior iliac spine; 6 . from the left acromion to the leftposterior superior iliac spine; 7. from the right posterior superior iliac spine to the right medial malleolus; 8 . from the leftposterior superior iliac spine to the left medial malleolus; 9. from the inferior angle of the right scapula to the inferior angle of the left scapula.Right Side view: 10. from the acromion to the sternal manubrium; 11. from the acromion to the mentus. Left Side view: 12 from the acromion to the sternal manubrium; 13. from the acromion to the mentus.

For data normalization, we measured the forearm length of each patient at the beginning and the end of treatment and the distances obtained by the software were divided by this value (14). Images were analyzed by three different examiners.

\section{Horses and riding equipment}

Two horses trained for hippotherapy were used, one of the Arabianbreed and the other Quarter with Persian breed, aged 8 and 9 years and $1.54 \mathrm{~m}$ and $1.48 \mathrm{~m}$ height, respectively. Horses were randomized selected for the sessions and showed docile behavior, obedience to the voice, indifference to unknown objects and noises, they leaned against on the ramp for riding, were fond of children and accepted all kinds of harnesses. For this study, we used the horse step gait.

In relation tothe riding equipment, it was used a blanket with feet of the subjects out of the stirrup, as it has been observed that in this condition there is an increased activation of the muscles of the neck (upper fibers of the trapezius), thorax (paraspinal), lumbar (multifidus) and abdominal (rectus abdominis) for 30 min session in children with DS (15). As safety procedures regarding the use of appropriate clothing and helmets, it was followed the guidelines of ANDE-Brazil.

\section{Statistical analysis}

Data statistically analyzed consisted of distance measurements determined previously, comparing the data before and after hippotherapy sessions. 
Data normality was checked with the ShapiroWilk test and homogeneity of variances with the Bartlett test. For comparisons data before and after hippotherapy sessions, we used the t-test. Data were analyzed using Sigma-Stat ${ }^{\circledR} 2.0$. Differences were considered statistically significant when the p-value was less than $5 \%$.

Also, the cluster analysis was applied for grouping different variables according to their similarity. Through this analysis, the groups are obtained by hierarchical clustering algorithm, making automatic grouping of data according to their similarity and representing the clusters in a dendrogram (representation of a hierarchy as a tree) (14).

\section{Results}

There was a good grouping, after the sessions, of the distances: from the right acromion to the right anterior superior iliac spine (var 1) and from the left acromion to the left anterior superior iliac spine (var 2) (Figures 3a and 3b). This finding was also confirmed by statistical analysis, represented in the right hemibody ( $p=0.0005)$ (Table 1a). The distance between the right anterior superior iliac spine and the right medial malleolus (var 3) was grouped with the distance from the left anterior superior iliac spine to the left medial malleolus (var 4) (Figures 3a and $3 b)$, confirmed by statistical analysis ( $p=0.0384$ ) (Table 1a). In the evaluation of the distances from the right acromion and the right posterior superior iliac spine (var 5) to the left acromion and the left posterior superior iliac spine (var 6), treatment promoted approximation of variables (Figures 3a and 3b). After the sessions, the analysis revealed a close grouping with smaller distance between variables 7 and 8 (Figures 3a and 3b), validated by statistical analysis, in the evaluation of the rear view of the right posteriorsuperior iliac spine to the right medial malleolus ( $\mathrm{p}=0.0001$ ) (Table $1 \mathrm{~b})$.

After treatment, the variable 10 became closer to variable 12 (Figure $3 b$ ), with $p=0.0306$ (Table 2). There was also significance of the right acromion to mentus, $\mathrm{p}=0.0270$ (Table 2).

The grouping of variables11 and 13 showed the best linkage with a shorter distance after the proposed treatment (Figures 3a and 3b). The statistical analysis evidenced that this deviation was present in the right side of the body, because in the left side view, there was no significant difference in the assessed distances.

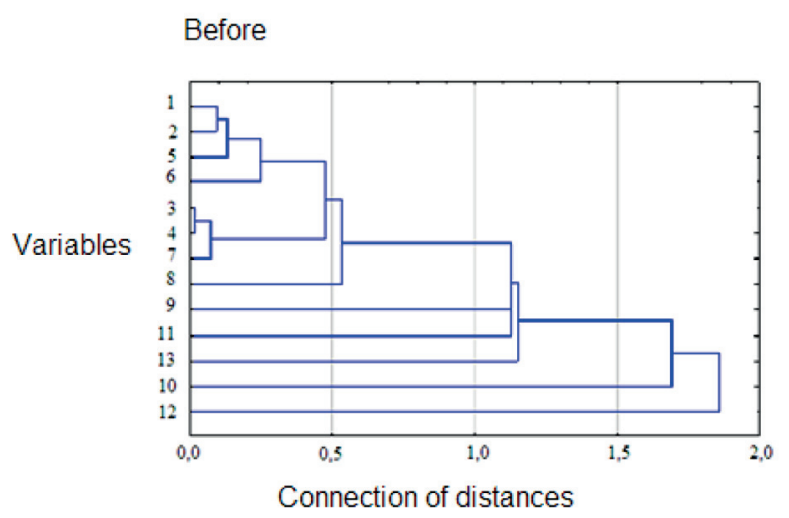

Figure 3a - Hierarchical Cluster analysis of individuals with Down syndrome before hippotherapy sessions, considering the following variables that indicate the distances between: 1 . the right acromion and the right anterior superior iliac spine; 2 . the left acromion and the left anterior superior iliac spine; 3. the right anterior superior iliac spine and the right medial malleolus; 4 . the left anterior superior iliac spine and the left medial malleolus; 5 . the right acromion and the right posterior superior iliac spine; 6 . the left acromion and the left posterior superior iliac spine; 7 . the right posterior superior iliac spine and the right medial malleolus; 8. the left posterior superior iliac spine and the left medial malleolus; 9 . the inferior angle of the right scapula and the inferior angle of the left scapula; 10. the right acromium and the manubrium; 11. the right acromium and the mentus; 12. the left acromium and the manubrium; 13. the left acromium and the mentus.

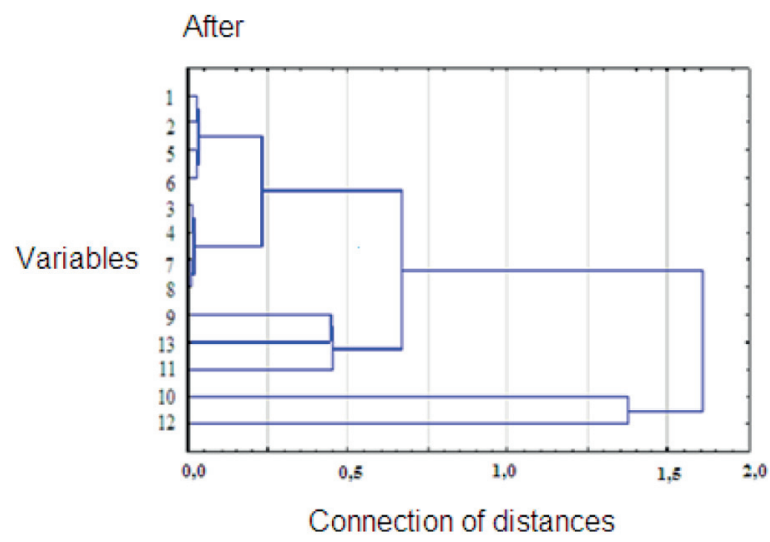

Figure $3 \mathbf{b}$ - Hierarchical Cluster analysis of individuals with Down syndrome after 27 sessions of hippotherapy, considering the following variables that indicate the distances between: 1 . the right acromion and the right anterior superior iliac spine; 2 . the left acromion and the left anterior superior iliac spine; 3. the right anterior superior iliac spine and the right medial malleolus; 4. the left anterior supe- 
rior iliac spine and the left medial malleolus; 5 . the right acromion and the right posterior superior iliac spine; 6 . the left acromion and the left posterior superior iliac spine; 7. the right posterior superior iliac spine and the right medial malleolus; 8 . the left posterior superior iliac spine and the left medial malleolus; 9 . the inferior angle of the right scapula and the inferior angle of the left scapula; 10. the right acromium and the manubrium; 11. the right acromium and the mentus; 12. the left acromium and the manubrium; 13. the left acromium and the mentus.

Table la - Postural analysis. Front view

\begin{tabular}{lccccc}
\hline \multicolumn{1}{c}{ Group $(\mathrm{n}=5)$} & $\begin{array}{c}\text { Bone } \\
\text { reference }\end{array}$ & $\begin{array}{c}\text { Acromium to } \\
\text { EIAS/D }(\mathrm{cm})\end{array}$ & $\begin{array}{c}\text { Acromium to } \\
\text { EIAS/E }(\mathrm{cm})\end{array}$ & $\begin{array}{c}\text { EIAS/D to } \\
\text { MM/D }(\mathrm{cm})\end{array}$ & $\begin{array}{c}\text { EIAS/E to } \\
\text { MM/E }(\mathrm{cm})\end{array}$ \\
\hline \multirow{2}{*}{ Before } & Mean & 0.24 & 0.46 & 0.44 & 0.23 \\
& \pm SEM & 0.01 & 0.03 & 0.07 & 0.02 \\
After & Mean & 0.5 & 0.49 & 0.28 & 0.28 \\
$\mathrm{p}$ - value & \pm SEM & 0.02 & 0.021 & 0.003 & 0.003 \\
\hline
\end{tabular}

Table $\mathbf{1 b}$ - Postural analysis. Rear view

\begin{tabular}{lcccccc}
\hline Group $(\mathrm{n}=5)$ & $\begin{array}{c}\text { Bone } \\
\text { reference }\end{array}$ & $\begin{array}{c}\text { Acromium to } \\
\text { EIPS/D }(\mathrm{cm})\end{array}$ & $\begin{array}{c}\text { Acromium to } \\
\text { EIPS/E }(\mathrm{cm})\end{array}$ & $\begin{array}{c}\text { EIPS/D to } \\
\text { MM/D (cm) }\end{array}$ & $\begin{array}{c}\text { EIPS/E to } \\
\text { MM/E }(\mathrm{cm})\end{array}$ & $\begin{array}{c}\text { AIE/D to } \\
\text { AIE/E }(\mathrm{cm})\end{array}$ \\
\hline \multirow{2}{*}{ Before } & Mean & 0.46 & 0.44 & 0.23 & 0.35 & 0.95 \\
& \pm SEM & 0.03 & 0.07 & 0.02 & 0.1 & 0.08 \\
After & Mean & 0.52 & 0.52 & 0.52 & 0.26 & 1.08 \\
p- value & \pm SEM & 0.02 & 0.02 & 0.02 & 0.004 & 0.11 \\
\hline
\end{tabular}

Note 1a and 1b: Statistical tests: t-test ${ }^{\star} \mathrm{p}<0.05$; Standard error of the mean ( \pm SEM); Distance from the acromium to the right anterior superior iliac spine (Acromium to (EIAS/D); Distance from the acromium to the left anterior superior iliac spine (Acromium to EIAS/E); Distance from the right anterior superior iliac spine to the right medial malleolus (EIAS/D to MM/D); Distance from the left anterior superior iliac spine to the left medial malleolus (EIAS/E to MM/E); Distance from the acromium to the right posterior superior iliac spine (Acromium to EIPS/D); Distance from the acromium to the left posterior superior iliac spine (Acromium to EIPS/E); Distance from the right posterior superior iliac spine to the right medial malleolus (EIPS/D to MM/D; Distance from the left posterior superior iliac spine to the left medial malleolus (EIPS/E to MM/E); Distance from the inferior angle of the right scapula to the inferior angle of the left scapula (AIE/D to AIE/E).

Table 2 - Postural analysis (Right side view)

\begin{tabular}{lccc}
\multicolumn{2}{c}{ Group $(\mathrm{n}=5)$} & Acromium/D to MN (cm) & Acromium/D to MT (cm) \\
\hline \multirow{2}{*}{ Before } & Mean & 2.23 & 1.31 \\
& \pm SEM & 0.08 & 0.09 \\
After & Mean & 3.63 & 1.67 \\
& \pm SEM & 0.44 & 0.15 \\
p-value & & 0.0306 & 0.0270 \\
\hline
\end{tabular}

Note: Standard error of the mean ( \pm SEM); distance from the right acromium to the manubrium (Acromium/D to MN); distance from the right acromium to the mentus (Acromium/D to MT). 


\section{Discussion}

The results of the present study, whose goal was to evaluate posture before and after hippotherapy, indicated favorable changesin postural alignment.

There is a high incidence of postural changes in children at school age, which can be corrected naturally during the growth (16). However, this approach is different in children with DS, who often show hypotonia, ligamentous laxity and muscle weakness, which are some of the changes affecting the musculoskeletal system thatlead to a delay in motor development and can contribute to a subsequent postural misalignment. These changes also promote the acquisition of abnormal patterns and changes in anatomical, morphological and mechanical axes, which provide an intrinsic stability to the skeleton, potentially triggering misalignments and orthopedic disorders in adulthood(17). In this study, individuals exhibited postural deviations evidenced by the difference in distance values and a smaller grouping of variables in the cluster analysis. According to the results, there was a high correlation within clusters indicating the distances analyzed after treatment, also statistically significant for many of the variables. Since the presentation of data in hierarchical clustering indicates a grouping of data with similar characteristics(14), this high correlation indicates a minor deviation of the measured distances, and therefore, less postural deviation; the right and left sides of the body of these childrenshowed a better alignment with each other, provided by hippotherapy. Thus, our results suggest improvements in shoulder alignment, assessed by the distance from the acromion to the anterior superior iliac spine, both on the right and on the left. It was also found an improvement in the alignment of the hip and lower limbs, measured by the variables that indicate the distance between the anterior superior iliac spine and the medial malleolus, on both sides. The distance between the right acromion and the manubrium demonstrated a better grouping with the distance from the left acromion to the manubrium, suggesting a decrease in kyphosis. In addition, there was a smaller protrusion and head alignment, evaluated by the grouping of the variables that indicate the distance between the right acromion and the mentus with the distance from the left acromion to the mentus.

Studies in the literature report that the effects after practice of hippotherapy included improvement in balance and increased range of motion (18, 19). A study that evaluated the trunk alignment in sitting position, using hippotherapy as treatment, showed symmetry in the pelvis weight transfer, further dissociation of pelvic girdle and cervical alignment (20). Other investigations report that the sensorimotor stimuli applied to the individual sitting on the horse generate greater muscle activation of the extensor muscle groups of the spine and muscle tone normalization for triggering biomechanical adjustments, facilitating postural control $(21,22,23)$. These data corroborate our findings, which demonstrated that the stimuli provided by hippotherapy contribute to a better alignment of biomechanical structures, especially in shoulder and hip alignment and thoracic kyphosis.

Additionally, changes in horse gait speed generate responses of straightening corporal and balance, allowing the development of dynamic postural stability and postural control $(11,24)$. On the other hand, even not using changes in horse gait speed during the hippotherapy sessions in this study, there was postural improvements in individuals with DS. Medical literature reports that when the practitioner is responding to horse movements, he/she should keep his/her head and torso on the support base to stabilize the vision and coordinate postural muscle synergies. The quantification of postural control allowed to measure changes during the treatment; in this way, the intervention with hippotherapy for children with DS improved their motor performance in fundamental motor skills (walking, running, and jumping); these improvements that may be related to the fact that the intervention staff maximizes time on the moving horse to allow children to respond to stimuli on an almost continuous basis. $(25,26,27)$.

The study of Grazziotin found an improved posture, more aligned shoulders, neck along aless anterior trunk and more upright posture after 27 sessions of hippotherapy (28). Further elucidating the beneficial effects of such treatment, it was possible to show a postural adjustment in individuals with Down syndrome in this study, after 27 sessions of hippotherapy with horse at step gait and at a constant speed. It is noteworthy that treatments targeting balance problems in individuals with DS should be performed focusing on assisting children in the development and refinement of postural synergies, enhancing motor coordination, the spatiotemporal relationship between various muscle groups working 
together, thereby improving the processes responsible for adjusting the posture(29). Hippotherapy has become widespread as a therapeutic agent justified by its goals of stimulating the individual as a whole, favoring the neuromotor functions. Nevertheless,hippotherapy collaborates in the active rehabilitation process of the individual participating in his/her growth and development (30).

Some limitations of this study involve the understanding of some children in standing still when photographed and the low number of subjects at the end of the study. However, the findings support the conclusion that the stimulus provided by the hippotherapy caused favorable changes in postural alignment.

\section{Conclusion}

By means of photogrammetry, before and after hippotherapy sessions, it is concluded that individuals with DS included in this study showed satisfactory changes in motor behavior. Such changes reflected in an improvement in static posture, better alignment of shoulders, head, hip, lower limbs, decreased kyphosis and head protrusion. It is therefore suggested that hippotherapy can improve the posture of subjects with DS. Nonetheless, the complexity of composing a representative group of individuals with DS, appropriate for the study proposed prevents the assertion that hippotherapy improves posture of subjects with DS. Otherwiseour findings can strengthen the indication found in the literature on the use of hippotherapy as a potential intervention for people with DS and postural changes.

\section{Acknowledgements}

The authors thank the financial support for this research provided by National Council for Scientific and Technological Development (CNPq), Coordination for the Improvement of Higher Education Personnel (CAPES), Minas Gerais State Research Foundation (FAPEMIG), Education and Research Foundation of Uberaba (FUNEPU) and Association of Parents and Friends of Intellectually Disabled Children of Uberaba (APAE).

\section{References}

1. Moreira LMA, El-Hani CN, Gusmão FAF. A síndrome de Down e sua patogênese: considerações sobre o determinismo genético.Rev Bras Psiquiatr. 2000;22:96-9. Portuguese.

2. Down JL.Observations on ethinic classification of idiots. London Hospital Clinical Lectures and Reports. 1866;3:259-62.

3. Dunn PM. Dr Langdon Down (1828-1896) and 'mongolism'. Arch Dis Child. 1991;66(7 Spec No):827-8.

4. Corrêa JCF, Oliveira AR, Oliveira CS, Corrêa FI. A existência de alterações neurofisiológicas pode auxiliar na compreensão do papel da hipotonia no desenvolvimento motor dos indivíduos com síndrome de Down?Fisioter Pesq. 2011;18(4):377- 81. Portuguese.

5. Polastri PF, Barela JA. Perception-Action Coupling in infants with Down syndrome: effects of experience and Pratice. Adap Phys Act Quart. 2005;22(1):39-56.

6. Blanco, JAC, Cabezas AM, Garrido MVO, Padilla CM. Análisis postural: prevención desde la fisioterapia. Revista Médica Internacional sobre el Síndrome de Down. 2011;15(1):41-4. Spanish.

7. Silveira MM, Wibelinger LM. Reeducação Postural com a Equoterapia. Rev Neurocienc. 2011;19(3):519-24. Portuguese.

8. Hammer A, Nilsagard Y, Forsberg A, Pepa H, Skargren E, Oberg B. Evaluation of therapeutic riding (Sweden)/hippotherapy (United States). A single-subject experimental design study replicated in eleven patients with multiple sclerosis. Physiother Theory Pract. 2005;21(1):51-77.

9. Liporoni GF, Oliveira APR. Equoterapia como tratamento alternativo para pacientes com sequela neurológica. Investigacao. 2005;5(1):22-9. Portuguese.

10. Janura M, Peham C, Dvorakova T, Elfmark M. An Assessment of the Pressure Distribution Exerted by a Rider on the Back of a Horse During Hippotherapy. Hum Mov Sci. 2009;28(3):387-93.

11. Zadnikar M, Kastrin A. Effects of hippotherapy and therapeutic horseback riding on postural control or balance in children with cerebral palsy: a meta-analysis. Dev Med Child Neurol. 2011;53(8):684-91. 
12. Projeto SAPO. 2009 [cited 2009 Feb 14]. Available from: http://www.sapo.incubadora.fapesp.br.

13. Santos MM, Silva MPC, Sanda LS, Alvez CRJ. Análise postural fotogramétrica de crianças saudáveis de 7 a 10 anos: confiabilidade interexaminadores. Rev Bras Fisioter. 2009;13(4):350-5. Portuguese.

14. Okama LO, Queiroz D, Spina LR, Miranda MBL, Curtarelli MB, Júnior M F, et al. Avaliação funcional e postural nas distrofias musculares de Duchenne e Becker. Conscientiae Saude. 2010;9(4).Portuguese.

15. Espindula AP, Simões M, Assis ISA, Fernandes M, Ferreira AA, Ferraz PF, et al. Material de montaria para equoterapia em indivíduos com síndrome de Down: estudo eletromiográfico.Conscientiae Saude. 2014;13(3):349-56.Portuguese.

16. Penha PJ, João SMA, Casarotto RA, Amino CJ, Penteado DC. Postural assessment of girls between 7 and 10 years of age. Clinics (Sao Paulo). 2005;60(1):9-16.

17. Gokce M, Purushottam A, David M, Roger F, Daniel W. Down syndrome: orthopedic issues. Curr Opin Pediatr. 2008;20(1):30-6.

18. Quint C, Toomey M. Powered Saddle and Pelvic Mobility: An investigation into the effects on pelvic mobility of children with cerebral palsy of a powered saddle which imitates the movements of a walking horse. Physiotherapy. 1998;84(8):376-84.

19. Kuczynski M, Slonka K. Influence of artificial saddle riding on postural stability in children with CP. Gait Posture. 1999;10(2):154-60.

20. Alves CN, Pettenuzzo TSA, Klimiuk BR, Santos RV. Equoterapia e o alinhamento do tronco na postura sentada do paralisado cerebral. Revista Equoterapia. 2003; 7:5-10.

21. Debuse D, Gibb C, Chandler C. An exploration of German and British physiotherapists' views on the effects of hippotherapy and their measurement. Physiother Theory Pract. 2005;21(4):219-42.

22. Pierobon JCM, Galetti FC. Estímulos sensório-motores proporcionados ao praticante de equoterapia pelo cavalo ao passo durante a montaria.Ensaios Cienc., Cienc. Biol. Agrar. Saúde.2008;12(2):63-79. Portuguese.
23. Shurtleff TL, Standeven JW, Engsberg JR. Changes in dynamic trunk/head stability and functional reach after hippotherapy. Arch Phys Med Rehabil. 2009;90(7):1185-95.

24. Ulrich BD, Haehl V, Buzzi UH, Kubo M, Holt KG. Modeling dynamic resource utilization in populations with unique constraints: preadolecents with and without Down syndrome. Hum Mov Sci. 2004;23(2):133-56.

25. Espindula AP, Ribeiro MF, Souza LAPS, Ferreira AA, Teixeira VPA. Avaliação muscular eletromiográfica em paciente com síndrome de Down submetidos à equoterapia. Rev Neurocienc. 2015;23(2):218-26. Portuguese.

26. Sterba JA, Rogers BT, France AP, Vokes DA, Warner R. Horseback riding in children with cerebral palsy: effect on gross motor function. Dev Med Child Neurol. 2002;44(5):301-8.

27. Champagne D, Dugas C. Improving gross motor function and postural control with hippotherapy in children with Down syndrome: case reports. Physiother Theory Pract. 2010;26(8):564-71.

28. Grazziotin PA. Equoterapia como recurso terapêutico nas alterações posturais -(Cifose Dorsal). Porto Alegre: Colégio Brasileiro de Estudos Sistêmicos; 2004. p. 56.Portuguese.

29. Rigoldi C, Galli M, Mainardi L, Crivellini M, Albertini G. Postural control in children, teenagers and adults with Down syndrome. Res Dev Disabil. 2011 Jan-Feb;32(1):170-5.

30. Espindula AP, Ribeiro MF, Ferreira AA, Teixeira VPA. Eletromiografia na atuação fisioterapêutica na prática clínica equoterápica. In: Soares DFG, Otone GA, Vieira MLN, Faíco MMM, Santos NC, Ferreira RC. Equoterapia Teoria e Prática no Brasil. Caratinga, MG (Brazil): Funec Editora; 2013. p. 417-34. Portuguese.

Received in $07 / 20 / 2014$ Recebido em 20/07/2014

Approved in 10/16/2015 Aprovado em 16/10/2015 
